\title{
Sporadic inclusion body myositis: the genetic contributions to the pathogenesis
}

\author{
Qiang Gang ${ }^{1,2^{*}}$, Conceição Bettencourt ${ }^{1}$, Pedro Machado ${ }^{2}$, Michael G Hanna ${ }^{1,2}$ and Henry Houlden ${ }^{1,2}$
}

\begin{abstract}
Sporadic inclusion body myositis (SIBM) is the commonest idiopathic inflammatory muscle disease in people over 50 years old. It is characterized by slowly progressive muscle weakness and atrophy, with typical pathological changes of inflammation, degeneration and mitochondrial abnormality in affected muscle fibres. The cause(s) of sIBM are still unknown, but are considered complex, with the contribution of multiple factors such as environmental triggers, ageing and genetic susceptibility. This review summarizes the current understanding of the genetic contributions to sIBM and provides some insights for future research in this mysterious disease with the advantage of the rapid development of advanced genetic technology. An international sIBM genetic study is ongoing and whole-exome sequencing will be applied in a large cohort of sIBM patients with the aim of unravelling important genetic risk factors for sIBM.
\end{abstract}

Keywords: Inclusion body myositis, Inclusion body myopathy, IBM, Genes, Genetics, Exome sequencing

\section{Introduction}

Sporadic inclusion body myositis (sIBM) is the commonest form of idiopathic inflammatory myopathy among individuals aged over 50 [1]. It has a male predominance and a prevalence of 1-71 people per million inhabitants has been reported in different populations, rising up to 139 per million among people over 50 years old (Table 1) [1-10]. These figures may be substantially underestimated due to frequent initial misdiagnosis of this disease [11-13]. Clinically, sIBM is characterised by progressive quadriceps femoris and deep finger flexors weakness and atrophy $[11,12]$. Many patients become wheelchair dependent and severely disabled $10-15$ years after symptom onset, although disease progression is heterogeneous $[12,13]$. Dysphagia, due to oesophageal and pharyngeal muscle involvement, affecting up to $80 \%$ of sIBM patients, can be a significant problem predisposing to malnutrition, pulmonary aspiration and pneumonia [11-13]. Muscle tissue in sIBM is characterised by the presence of inflammatory and degenerative features. Inflammatory features include endomysial inflammation, partial invasion (invasion

\footnotetext{
* Correspondence: q.gang@ucl.ac.uk

${ }^{1}$ Department of Molecular Neuroscience, Institute of Neurology, University College London, Queen Square, London WC1N 3BG, UK

${ }^{2} \mathrm{MRC}$ Centre for Neuromuscular Diseases, Institute of Neurology, University College London, London WC1N 3BG, UK
}

of non-necrotic fibres by inflammatory cells) and upregulation of major histocompatibility complex (MHC) class I [14]. Degenerative features include the formation of rimmed vacuoles, tubulofilaments seen on electron microscopy and the accumulation of many myotoxic proteins (including amyloid, p62 and TAR DNA-binding protein-43 (TDP-43)), termed as 'inclusions' [15]. The observation of ragged-red, cytochrome c oxidase (COX) deficient and succinate dehydrogenase positive fibres reflects mitochondrial changes in SIBM muscle tissue [16].

The clinical diagnosis of sIBM is confirmed by muscle biopsy assisted by the clinical phenotype, electromyography (EMG), determination of serum muscle-enzyme levels and muscle imaging with MRI [11]. Currently, the Griggs Criteria [17,18], the European Neuromuscular Centre (ENMC) Criteria $[19,20]$ and the MRC Centre for Neuromuscular Diseases Criteria [21,22] are the most widely used diagnostic criteria for sIBM. However, the aetiology of sIBM is still unclear and no effective treatment is available [11,23].

sIBM is a complex disease. The primary pathogenic mechanism is still hotly debated and it is believed that many factors including environmental factors contribute to the disease process. There are many clinically and/or histologically sIBM-like muscle diseases with known genetic defects, which may provide clues to understand 
Table 1 Prevalence of sporadic IBM in different populations

\begin{tabular}{|c|c|c|c|c|}
\hline Study & Region & Diagnostic criteria & $\begin{array}{l}\text { Prevalence } \\
\text { (per million population) }\end{array}$ & $\begin{array}{l}\text { Prevalence }>50 \text { yrs } \\
\text { (per million population) }\end{array}$ \\
\hline Lingberg et al. [2] & Sweden & Biopsy and clinical data & 2.2 & $\mathrm{n} / \mathrm{a}$ \\
\hline Kaipiainen-Seppanen and Aho [4] & Finland & Not mentioned & 0.9 & $\mathrm{n} / \mathrm{a}$ \\
\hline Philips et al. [5] & Australia & Griggs et al. criteria & 9.3 & 35.3 \\
\hline Badrising et al. [3] & Netherlands & ENMC criteria & 4.9 & 16 \\
\hline Felice and North (Connecticut, USA) [6] & Connecticut, USA & Griggs et al. criteria & 10.7 & 28.9 (>45 yrs) \\
\hline Needham et al. [1] & Western Australia & Clinical and biopsy criteria & 14.9 & 51.2 \\
\hline Wilson et al. [7] & Olmsted County, USA & Griggs et al. criteria & 71 & $\mathrm{n} / \mathrm{a}$ \\
\hline Oflazer et al. [8] & Istanbul, Turkey & $\begin{array}{l}\text { Own criteria from the study } \\
\text { (biopsy and clinical data) }\end{array}$ & 1.0 & 6.0 \\
\hline \multirow[t]{2}{*}{ Suzuki et al. [9] } & Japan & Clinical and biopsy criteria & 1.3 (in 1991) & $\mathrm{n} / \mathrm{a}$ \\
\hline & & & 9.8 (in 2003) & $\mathrm{n} / \mathrm{a}$ \\
\hline Tan et al. [10] & South Australia & Biopsy and clinical data & 50.5 & 139.3 \\
\hline
\end{tabular}

the pathogenesis of sIBM. In this review we will comprehensively summarize known and candidate genetic susceptibility risk factors for sIBM.

\section{Muscle disorders similar to sIBM \\ Familial inclusion body myositis}

There are several IBM case reports of two or more affected siblings in the same family [24-26] and one report of affected twins [27]. Because of the clinical and histological similarities with sIBM these cases have been called familial inclusion body myositis (fIBM). Human leukocyte antigen (HLA) class II genotypes were reported in a strong association with some families, particularly the $D R 3$ allele $\left(D R B^{* 0301 / 0302)}\right.$ in four western families [24,25] and the $D R 15(2) / D R 4$ (DRB1*1502/0405) in two Japanese sisters [26]. The fIBM and sIBM share not only similar clinical, biological, MRI and histopathological features but also similar genetic markers, which indicate the possibility that the two subsets of IBM may share the same susceptibility determinants to the disease development and also highlight the genetic predisposition for sIBM pathogenesis.

\section{Hereditary inclusion body myopathies}

Hereditary inclusion body myopathies (hIBM) include several autosomal-recessive and autosomal-dominant muscle disorders with various clinical presentations, but with a number of pathological features similar to those of sIBM, including rimmed vacuoles, protein accumulations and tubulofilaments on electron microscopy. Patients with hIBM can be distinguished from sIBM by the earlier age of onset, rarity of inflammatory features and negative $\mathrm{MHC}$ class I expression, hence the term 'myopathy' instead of 'myositis' [28]. The hIBM can be grouped according to their mode of inheritance and genetic mutations (see hIBM subtypes in Table 2, and details in a previous IBM genetics review [29]).

\section{Other rimmed vacuolar myopathies}

Beyond the above conditions, there are various other neuromuscular disorders showing rimmed vacuoles in the muscle tissue, which make the differential diagnosis of sIBM even wider. Mutated genes have also been found in these called 'rimmed vacuolar myopathies', such as oculopharyngeal muscular dystrophy (OMIM\#164300), $\mathrm{X}$-linked recessive Emery-Dreifuss muscular dystrophy (OMIM\#310300), limb girdle muscular dystrophy (LGMD) type 2G (OMIM\#601954), LGMD type 1A (OMIM\#159000), LGMD type $1 \mathrm{G}$ (OMIM\#609115), and rigid spine syndrome (OMIM\#602771) [29]. Some intracellular Alzheimer's-like protein accumulations, including amyloid proteins, amyloid$\beta$ Protein Precursor (A $\beta$ P P), phosphorylated tau and presenilin-1, among others, have been found in extensive overlap between sIBM and myofibrillar myopathies [31].

Overall, these common features raise the possibility that sIBM and these diseases share certain etiologic factors. Indeed, a recent study [32], reported that the p.V805A variant in $M Y H 2$ (gene associated with hIBM3) significantly increased the risk of developing sIBM $(R R=12.2)$. However, none of the patients with that variant reported joint contractures or external ophthalmoplegia, a family history of IBM or consanguineous marriage [32]. This was the first report of a $M Y H 2$ gene mutation described in non-familial cases. Immunohistochemical studies of myosin heavy chain isoforms showed atrophy or loss of muscle fibres expressing myosin heavy chain IIa or IIx, which may provide important clues for establishing the pathogenicity of this variant. In the same study, a novel missense mutation c.1719G > A (p.V566M) in the LIM domain binding 3 gene ( $L D B 3$, also known as $Z A S P$; causative gene for zaspopathy, a subtype of myofibrillar myopathies), coding for Z-band alternatively spliced PDZ-motif-containing protein, was reported in one of the patients [32]. This finding indicates $L D B 3$ mutations might 
Table 2 Hereditary inclusion body myopathy subtypes (further detailed by Needham et al. [29])

\begin{tabular}{|c|c|c|c|c|}
\hline Hereditary IBM (hIBM) subtypes & OMIM\# & Disease inheritance & Genes & Function of coding proteins \\
\hline $\begin{array}{l}\text { Inclusion body myopathy } 2 \text { - } \\
\text { hlBM2 (distal myopathy with } \\
\text { rimmed vacuoles -DMRV/Nonaka } \\
\text { myopathy) }\end{array}$ & $600737(605820)$ & Autosomal-recessive & $\begin{array}{l}\text { UDP-N-acetylgucosamine-2- } \\
\text { epimerase/N-acetylmannosamine } \\
\text { kinase (GNE) gene }\end{array}$ & $\begin{array}{l}\text { A rate-limiting enzyme in the sialic } \\
\text { acid biosynthetic pathway, involved } \\
\text { in sialylation of muscle glycoproteins, } \\
\text { and cellular homeostasis }\end{array}$ \\
\hline $\begin{array}{l}\text { A leukoencephalopathy and a } \\
\text { vacuolar myopathy resembling IBM }\end{array}$ & n/a & Autosomal-recessive & $\begin{array}{l}\text { Laminin alpha } 2 \text { (LAMA2) } \\
\text { gene [30] }\end{array}$ & $\begin{array}{l}\text { An extracellular protein of basement } \\
\text { membrane, mediates the attachment, } \\
\text { migration, and organization of cells into } \\
\text { tissues during embryonic development }\end{array}$ \\
\hline $\begin{array}{l}\text { hIBM with congenital joint } \\
\text { contractures, ophthalmoplegia } \\
\text { and rimmed vacuoles - hIBM3 }\end{array}$ & 605637 & Autosomal-dominant & $\begin{array}{l}\text { Myosin heavy chain Ila (MYHz; } \\
\text { previously known as MHClla) } \\
\text { gene }\end{array}$ & $\begin{array}{l}\text { A member of Class II or conventional } \\
\text { myosin heavy chains, functions in } \\
\text { skeletal muscle contraction }\end{array}$ \\
\hline $\begin{array}{l}\text { Inclusion body myopathy with } \\
\text { early-onset Paget's disease of the } \\
\text { bone (PDB) and frontotemporal } \\
\text { dementia (FTD) (IBMPFD) }\end{array}$ & 167320 & Autosomal-dominant & $\begin{array}{l}\text { Valosin-containing protein } \\
(V C P) \text { gene }\end{array}$ & $\begin{array}{l}\text { A member of the 'ATPases associated } \\
\text { with a variety of activities (AAA-ATPase)' } \\
\text { superfamily, is involved in a variety of } \\
\text { cellular activities, such as cell cycle control, } \\
\text { membrane fusion and the ubiquitin- } \\
\text { proteasome degradation pathway }\end{array}$ \\
\hline
\end{tabular}

cause abnormalities in the Z-band in skeletal muscle resulting in the disease observed in this patient. Further studies with a larger number of cases will be needed to clarify the contribution of these genes to the pathogenesis of sIBM. In addition, investigations should be carried out on more hereditary myopathies candidate genes, including $\alpha-\mathrm{B}$ crystalline $(C R Y A B)$, dystrophin $(D M D)$ and myotilin (MYOT) in the future.

\section{Pathogenesis of sIBM and its predisposing genetic factors}

Currently there are two most popular theories for the pathogenesis of SIBM - an autoimmune pathway and a degeneration pathway. In addition, ageing is also considered an important factor contributing to mitochondrial abnormalities (Figure 1).
The theory of an inflammation pathway stands for viral or inflammatory triggering factors leading to the clonal expansion of $\mathrm{CD}^{+} \mathrm{T}$ cells and $\mathrm{T}$ cell-mediated cytotoxicity, which ultimately result in damage or death of muscle fibres [33]. This theory is supported by the increased occurrence of sIBM in the presence of autoimmune disorders and HIV and HTLV-1 infection [34]. Degenerative changes and endoplasmic reticulum (ER) stress are considered as secondary mechanisms induced by increased intracellular cytokines and chemokines [33]. The degree of mitochondrial changes and muscle atrophy were suggested to be strongly correlated with the severity of inflammation in a recent study [35].

However, sIBM is poorly responsive to even vigorous immunosuppression. Even where there is histopathological

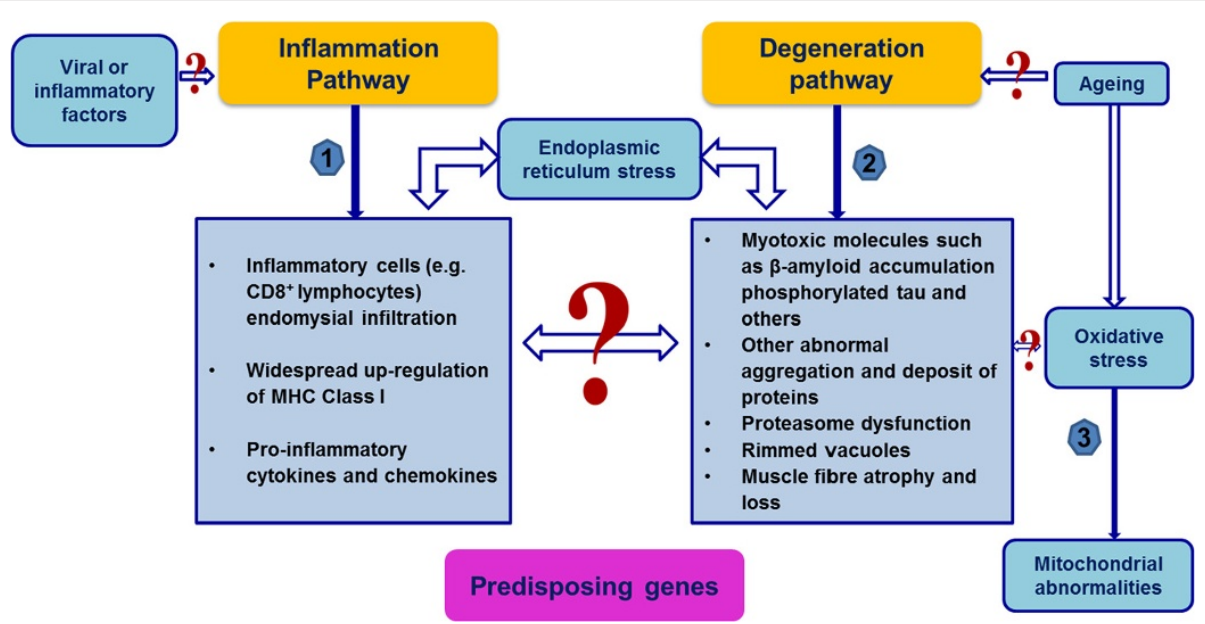

Figure 1 Possible pathogenic pathways of sIBM - multifactorial mechanisms involved. An inflammation pathway and a degeneration pathway constitute the two most popular theories for the pathogenesis of sIBM. Ageing is also considered an important factor contributing to mitochondrial dysfunction in result of oxidative stress in the muscle tissue. However, it is still not clear which is the primary cause of the disease, and how these potential pathways interact. Predisposing genes could also contribute to the development and progression of the disease. 
evidence that inflammation was reduced, this was not accompanied by clinical improvement. Therefore, some investigators are supporting a degenerative hypothesis over inflammation as the primary pathogenesis of sIBM. The identification of aberrant protein aggregates in SIBM vacuolated muscle fibres has shown the remarkable parallels of those features in brain tissue of Alzheimer's disease (AD) and Parkinson's disease with Lewy bodies. This theory suggests that inflammation is secondary to the degeneration-associated processes in sIBM muscle fibres [36] including: 1) multiple protein aggregates [37], 2) abnormal accumulation of lipoprotein receptors and free cholesterol [38], 3) oxidative stress [39], 4) inhibition of the 'ubiquitin-proteasome system' (UPS) [40], 5) endoplasmic reticulum stress [41], and 6) impaired autophagy-lysosome pathway [41]. Furthermore, myonuclear disintegration is also involved in the pathogenic process leading to the formation of rimmed vacuoles. This results in a severe consequence that is a progressive reduction of the number of myonuclei and further progressive muscle atrophy [42].

Despite sIBM not being an inherited Mendelian disease, multiple genetic risk factors are being shown likely to play important roles in the development and progression of sIBM. A list of possible susceptibility genes that could be important candidate genes for understanding the pathogenesis of sIBM is shown in Table 3. Furthermore, the prevalence of sIBM differs between different ethnic populations. This is likely due to differences in genetic makeup of different racial/ethnic groups and differences in the environmental factors of different geographical regions [29].

\section{Genetic factors related to inflammatory changes in SIBM} Major histocompatibility complex

Garlepp and colleagues first reported the strong association of $H L A-D R 3$ and the extended 8.1 ancestral haplotype $(A H)$ with sIBM [57]. This association has subsequently been confirmed in a series of further studies in Caucasians with $H L A-A * 01,-B * 0801,-D R B 1 * 0301,-D R B 1 * 0101$, $-D R B 1 * 1301,-D Q B 1 * 0201,-D Q A 1 * 05$ [58-65]. Furthermore, Rojana-udomsart and colleagues reported that the risk factors $H L A-D R B 1 * 0301$ and $* 1301$ also influence on the age at onset and the severity of muscle weakness
[65]. These results indicate that the interactions at $H L A-D R B 1$ locus may contribute to both disease susceptibility and clinical phenotype. Other alleles and haplotypes have also been associated with increased risk of sIBM, including the 35.2AH (HLA-B*3501, $-D R B 1 * 0101)$ in Caucasians [63] and the 52.1AH (HLA-B*5201, $D R B 1 * 1502)$ in Japanese [66]. Interestingly, a number of HLA alleles and haplotypes, including HLA-DR53 and HLA-DRB1*0401, *0701, *0901, "1101, *1501, HLA$D R B 1 * 0301 / * 0401$ and HLA-DRB1*0301/*0701 diplotypes, and $H L A-D R B 1 * 1501$, were found protective for sIBM [58,65,67].

A potential region of $\mathrm{MHC}$-associated susceptibility genes was first defined between $H L A-D R$ and $C 4$ [43], and then it was suggested in the border of the Class II and III regions, between $H L A-D R B 1$ and pre-B-cell leukemia homeobox2 (PBX2, also known as HOX12) [63]. A further recombination mapping was applied consisting of three separate cohorts to refine the probably 8.1 AH-derived sIBM susceptibility region from butyrophilin-like MHC class II-associated gene (BTNL2) to telomeric of HLA$D R B 1$ including three protein-coding genes - part of $B T N L 2, H L A-D R A$ and $H L A-D R B 3$ [68]. Other genes in this region have also been considered as candidate genes, such as notch 4 gene (NOTCH4; a transmembrane receptor which regulates cell fate decisions), advanced glycosylation end product-specific receptor gene ( $A G E R$, previously known as $R A G E$ ), testis-specific basic protein gene (C6orf10, also known as TSBP), and G-protein signalling modulator 3 gene (GPSM3, previously known as G18) [43,63].

Two NOTCH4 gene polymorphisms (rs422951 and rs72555375) have shown a strong association (OR > 2) with SIBM in two independent Caucasian cohorts [69]. These variants (or other variants in linkage disequilibrium with them) may play a role in sIBM pathogenesis by generating antigenic peptides and can be regarded as markers for sIBM susceptibility. They may also influence the binding and affinity of notch 4 receptor and the presentation of the gene product at the cell surface, respectively [69].

The MHC contains important genetic contents which have been reported as being associated with sIBM and among them 8.1AH which is predominant in Caucasians, supporting an immune-mediated mechanism underlying

Table 3 Summary of possible susceptibility genes for sIBM based on current research and discussed in this review

\begin{tabular}{ll}
\hline Classification & Regions/Genes \\
\hline Immune-associated genes & MHC region [43]; NT5C1A gene [44]. \\
Degenerative-associated genes & APP gene [45]; PSEN gene [46]; DYSF gene [47]; APOE gene [48]; MAPT gene [49]; \\
& PRNP gene [50]; SERPINA3 gene [51]; TARDBP gene [52]; hnRNPA1 and hnRNPA2B1 \\
& genes [53]; C90rf72 [54]. \\
mtDNA-associated sequences/genes & mtDNA deletions [55]; Nuclear coding mitochondrial genes: TYMP, SLC25A4, C10orf2, \\
& POLG1, and TOMM40 gene [16,56]. \\
\hline
\end{tabular}


sIBM. Identification of the actual genes within the MHC will be crucial to understand the role of $\mathrm{MHC}$ in the pathogenesis of sIBM.

\section{Other autoimmune factors}

An autoantibody against the cytoplasmic $5^{\prime}$-nucleotidase 1A (cN1A; NT5C1A) was recently identified in sIBM by two independent groups $[44,70,71]$. cN1A, as a member of the family of $5^{\prime}$-nucleotidases, is a muscle-specific enzyme catalysing the hydrolysis of nucleotide to nucleosides. It is involved in a variety of functions including the physiological control of energy balance, metabolic regulation, and cell replication [72]. By immunohistochemistry, the accumulation of $\mathrm{cN} 1 \mathrm{~A}$ in perinuclear regions and rimmed vacuoles in both SIBM and fIBM muscle fibres indicates that $\mathrm{cN} 1 \mathrm{~A}$ protein might have a potential contribution during myonuclear degradation [44]. Although exome or whole genome sequencing performed in 19 patients did not detect any proteinaltering variants in both $N T 5 C 1 A$ and $N T 5 C 1 B$ genes [44], the genes encoding for the $\mathrm{cN1}$ A protein and a functionally related protein, respectively, are still important genetic candidates for understanding the relationship between SIBM autoimmunity and myofiber degeneration, and worth further genetic investigation.

\section{Candidate genetic factors related to degenerative changes in SIBM \\ $\beta$-amyloid (APP) and presenilin (PSEN)}

It has been widely recognized that there are abnormal accumulations of beta-amyloid $(\mathrm{A} \beta)$ protein, $\mathrm{N}$-terminal and $\mathrm{C}$-terminal of beta-amyloid precursor protein $(A P P)$, and A PPP-mRNA in both sIBM and hIBM muscle fibres $[45,73,74]$. A $\beta 42$ is considered more cytotoxic and more prone to self-association and oligomerization than $A \beta 40$, thereby exerting a detrimental role in $\mathrm{AD}$ brain [75]. Similarly, increased A $\beta 42$ oligomers were demonstrated preferentially in sIBM affected fibres [76] and also in plasma from patients with sIBM [77]. These indicate that the intra-muscle fibre accumulation of $A \beta 42$ oligomers in sIBM contributes to the pathogenic cascade [76]. The mechanisms of overexpression of APP gene in sIBM have not been fully understood. The fact that mutations in exons 16 and 17 of APP gene have been found to be pathogenic in $\mathrm{AD}$, resulting in early-onset familial $\mathrm{AD}$, suggests that mutations in this gene might also play a role in sIBM. In line with a previous small study [78], no coding APP mutations were found in our 58 sIBM cases.

Abnormal accumulation of presenilin proteins occurs in the brains of both sporadic and familial AD patients. Autosomal dominant inheritance of mutations in presenilin 1 (PSEN1) and presenilin 2 (PSEN2) genes are also found to be responsible for early onset familial $A D$, with mutations in PSEN1 gene as the most common cause
[79]. The exact roles of presenilin are still not clear, but it has been considered that mutations in presenilin genes cause increased synthesis of the cytotoxic A $\beta 42$ [80]. Abnormal accumulation of presenilin 1 protein was also reported immunohistochemically in muscle fibres of both sIBM and autosomal-recessive hIBM [46]. This indicates there might be some similarities shared between $\mathrm{AD}$ and IBM in pathogenic mechanism of presenilin deposits; however, mutations in PSEN1 and PSEN2 have not been investigated in either sIBM or hIBM cases.

\section{Dysferlin (DYSF)}

Dysferlin is a modular type II transmembrane protein newly identified as a binding partner of $A \beta P P$ that coaggregates with $\mathrm{A} \beta 42$ in sIBM muscle fibres [47]. In normal human muscle, dysferlin is immunohistochemically present in the muscle fibre sarcolemma and involved in plasmalemmal repair after injury as well as in T-tubule contraction and calcium homeostasis. Mutations in DYSF gene are known to cause a range of autosomal recessive myopathies, called dysferlinopathies including Miyoshi myopathy and limb girdle muscular dystrophy type 2B (LGMD2B) [81]. Similarly to dysferlinopathies, dysferlin is prominently reduced in the muscle fibre sarcolemma in SIBM muscle biopsies [47]. In addition, there is abnormal distribution of dysferlin into the cytoplasmic protein aggregates which co-localise with A $\beta 42$ aggregates. Accordingly, it is suggested that mutation(s) in DYSF gene might link to the pathogenesis of sIBM though the possible mechanisms is unknown [47].

\section{Apolipoprotein E (APOE)}

ApoE protein deposits but not mRNA have been identified in both sIBM and hIBM muscle fibres $[82,83]$. The $A P O E \varepsilon 4$ allele is recognized to be an important risk factor for developing late-onset AD. Several studies have been carried out to investigate the roles of $A P O E$ alleles in sIBM. Only one study of a cohort of 14 Australian sIBM patients suggested that $\varepsilon 4$ allele may be a susceptibility factor for the development of sIBM [84]. However, this association was not replicated in subsequent studies in Europe and USA [48,51,85-87]. A study in a larger cohort $(\mathrm{N}=57)$ [48], including also a meta-analysis, argues against a role of $A P O E \varepsilon 4$ allele as a susceptibility factor for developing SIBM. However, the authors demonstrated a non-significant trend towards an earlier age at onset in patients with the $A P O E \varepsilon 2$ allele [48].

Our preliminary data (58 sIBM cases from UK, USA and two European countries) is consistent with the above meta-analysis with respect to the association with $A P O E$ $\varepsilon 4$ allele. Interestingly, we found a statistically significant decreased frequency of $A P O E$ genotype $\varepsilon 2 / \varepsilon 3$ (p-value = 0.026) in the patient group compared with our British control individuals (unpublished data), and thus we found 
an association between $\varepsilon 2$ allele and a reduced risk of developing sIBM (Table 4). ApoE may play a role in the A $\beta$ PP pathway, as ApoE protein was found to co-localise with Congo red-positive $\beta$-amyloid deposits in SIBM cases. However, it is difficult to elucidate actual influences of $A P O E$ alleles on the development of sIBM, mainly because of the genetic heterogeneity of this disease.

\section{Phosphorylated Tau (MAPT)}

Accumulation of phosphorylated-tau is widely known to be another major protein present in sIBM muscle aggregates, which is strikingly similar with those found in taupathies which share hyperphosphorylated deposited tau protein in the brain [88]. Different microtubule-associated protein tau $(M A P T)$ gene mutations have been identified in many different tauopathies including AD, frontotemporal dementia and Parkinsonism linked to chromosome 17 (FTDP-17), progressive supranuclear palsy (PSP) and corticobasal degeneration (CBD). The majority of them affect exons 9-13 [89]. In addition to MAPT mutations, a common extended haplotype (H1) in $M A P T$ appears to be a risk factor for sporadic PSP [49]. A 238 bp deletion in $M A P T$ intron 9 is inherited as a part of the less common H2 sub-haplotype [49]. We analysed this deletion polymorphism (del-In9) in 81 sIBM DNA cases and 159 British healthy controls, but no significant differences were found between the two groups.

\section{Alpha-1-antichymotrypsin (SERPINA3)}

Alpha-1-antichymotyrpsin ( $\alpha 1 \mathrm{ACT}$; SERPINA3, previously known as $A C T$ ) is considered a major acute-phase protein and belongs to the serpin superfamily specifically inhibiting serine proteases. Similarly to AD brains, abnormal accumulations of $\alpha 1 \mathrm{ACT}$, located closely with $\beta$-amyloid protein containing ubiquitinated amyloid plaques, have been described in sIBM muscle [90]. Though genotype of SERPINA3/AA (rs4934) was found to alter the AD risk associated with $A P O E \varepsilon 4 / \varepsilon 4$ genotype [91], this correlation was not found in a cohort of 35 sIBM patients [51]. It might also be due to the small size of the patients' cohort, which indeed lacked cases with the $A P O E \varepsilon 4 / \varepsilon 4$ genotype.

\section{Prion (PRNP)}

Prion protein and mRNA (normal cellular isoform PrPc) have been described as being abnormally accumulated in vacuolated muscle fibres in both sIBM and hIBM $[92,93]$. Lampe et al. reported that homozygosity for methionine at codon $129(\mathrm{M} / \mathrm{M})$ of the prion protein $(P R N P)$ gene was more prevalent in SIBM (14 of 22 patients, 64\%), when compared with controls [50]. But this finding was not replicated in later studies with larger cohorts $(51.2 \% \mathrm{M} / \mathrm{M}$ [94] and our unpublished data $40 \% \mathrm{M} / \mathrm{M})$.

\section{TAR DNA-binding protein (TARDBP) and other heterogeneous nuclear ribonucleoproteins ( $h n R N P s)$}

A predominantly nuclear heterogeneous nuclear ribonucleoprotein (hnRNP) TAR DNA-binding protein-43 (TDP-43) is found as a major component of ubiquitinated inclusions in amyotrophic lateral sclerosis (ALS) and frontotemporal lobar dementia (FTLD-U). Mutations in TARDBP have been detected in both sporadic and familial forms of ALS [95]. Several recent studies [52,96-98] have detected sarcoplasmic TDP-43 inclusions in SIBM muscle fibres, which contrast with predominately nuclear immunostaining observed in normal tissue [52]. Similar TDP-43 deposits were also identified in IBMPFD, hIBM2 and other myofibrillar myopathies [97]. The similarities between these changes in sIBM muscle and those seen in brain tissue of ALS and FTLD-U suggest that SIBM may share some pathological pathways with these two diseases. TDP-43 could potentially interfere with the normal regulation of gene expression at the transcriptional level, regulating gene splicing and stabilizing extranuclear RNAs that maintain myofibre protein production. But exonic mutations in TARDBP gene have not yet been examined in a sIBM.

Abnormalities in the distribution of two other hnRNPs, hnRNPA1 and hnRNPA2B1, were identified in sIBM

Table 4 Frequency of $A P O E$ alleles in different studies

\begin{tabular}{llllll}
\hline Study & Country & $\begin{array}{l}\text { Number of alleles } \\
\text { (cases/controls) }\end{array}$ & $\begin{array}{l}\varepsilon 2 \text { allele } \\
\text { (controls) }\end{array}$ & $\begin{array}{l}\varepsilon 3 \text { allele } \\
\text { (controls) }\end{array}$ & $\begin{array}{l}\varepsilon 4 \text { allele } \\
\text { (controls) }\end{array}$ \\
\hline Garlepp et al. [84] & Australia & $28 / 344$ & $0.07(0.061)$ & $0.69(0.811)$ & $0.29(0.128)$ \\
Harrington et al. [86] & UK & $22 / 116$ & $0(0.086)$ & $0.818(0.767)$ & $0.182(0.147)$ \\
Love et al. [87] & UK & $82 / 5008$ & $0.05(0.08)$ & $0.79(0.79)$ & $0.16(0.13)$ \\
Askanas et al. [85] & USA & $22 / 70$ & $0.09(0.10)$ & $0.86(0.79)$ & $0.05(0.11)$ \\
Gossrau et al. [51] & Germany & $70 / 112$ & $0.1(0.036)$ & $0.757(0.848)$ & $0.143(0.116)$ \\
Needham et al. [48] & Australia & $114 / 344$ & $0.044(0.061)$ & $0.825(0.811)$ & $0.132(0.128)$ \\
Present study (our unpublished data)* & UK, USA and two European countries & $116 / 1540$ & $0.07(0.13)$ & $0.77(0.73)$ & $0.16(0.14)$ \\
\hline
\end{tabular}

*All participants gave their written informed consent and the study was approved by the National Research Ethics Service (NRES) Committee London - Queen Square (REC reference: 12/LO/1557). 
muscle fibres [53]. Similarly to TDP-43, these proteins were also depleted in myonuclei and form part of sarcoplasmic aggregates in sIBM muscle [53]. This further suggests that sIBM myofibre injury might be linked to disrupted RNA homeostasis [99], since there is depletion of these genes at the protein but not at the mRNA level [53]. Mutations in hnRNPA1 and hnRNPA2B1 have been identified in familial multisystem proteinopathy with similar myonuclei depletion and sarcoplasmic aggregates [100]. These genes constitute, therefore, good candidates to be further investigated in SIBM patients.

\section{C9orf72 repeat}

An expanded GGGGCC hexanucleotide repeat in the noncoding region of $C 9$ orf 72 has been identified as the most common genetic cause of familial ALS, FTLD or a combination of both phenotypes and TDP-43-based pathology (FTLD-TDP) [54]. In a recent study, it was suggested that mutations in C9orf72 may involve disrupted protein degradation [101]. Therefore, we hypothesized that genetic defects in C9orf72 might also play a role in the pathogenesis of sIBM. Fifty-eight sIBM cases were analysed for $C 9$ orf 72 repeat by our group, but no expanded repeats were found.

\section{Mitochondrial DNA abnormalities (mtDNA deletions) and sIBM}

Mitochondrial abnormalities are another important pathological feature in sIBM muscle biopsies, consisting of ragged-red fibres and mostly showing enzyme histochemical deficiency of COX activity. These changes are more prevalent in SIBM than in polymyositis, dermatomyositis and normal ageing muscle fibres [102]. It is therefore of great interest to investigate another group of susceptibility factors - mitochondrial DNA (mtDNA). An accumulation of mtDNA molecules with large-scale deletions was found in many COX-deficient ragged-red fibres of sIBM patients (e.g. [103]), with multiple different deletions in different muscle fibres but usually one predominant type of mtDNA deletion present in each COX-deficient fibre [55,104]. Thirty-three different deletions were identified by sequencing four patients with sIBM. The majority of mtDNA deletion breakpoints identified in sIBM muscle fibres span from the region of nt8029-8032 to the region of nt1606616078 [55] which are similar to those found in normal ageing and in autosomal dominant progressive external ophthalmoplegia (adPEO). These indicate that there may be a shared mechanism for the generation of mtDNA deletions in normal ageing, sIBM and adPEO. AdPEO and other hereditary disorders with multiple mtDNA deletions have been found associated with mutations in some nuclear genes, such as thymidine phosphorylase gene (TYMP, previously known as ECGF1), solute carrier family 25 (mitochondrial carrier; adenine nucleotide translocator) member 4 gene (SLC25A4, previously known as $A N T 1$ ), chromosome 10 open reading frame 2 (C10orf2) and polymerase gamma 1 (POLG1), which are important for mtDNA maintenance and replication [16]. Putative defects in these nuclear genes may directly or indirectly affect sIBM muscle. Notwithstanding no mutations in these genes were identified in sIBM cases, there is not enough evidence to exclude these genes as possible candidates. The reason for the accumulation of mtDNA deletions in sIBM muscle fibres is still unclear and no correlation between the presence of deletions and gender, age, or the main clinical features has been found so far $[16,104]$. But similar to the normal ageing muscle, mtDNA mutations in SIBM may be involved in the muscle atrophy and weakness.

In addition to mtDNA deletions, mutations at mtDNA nucleotide positions 3192, 3196, 3397 and 4336, which are associated with late-onset $\mathrm{AD}$, are possible risk factors for sIBM. In SIBM cases only the frequency of the common $16311 \mathrm{C}$ variant has been found more frequent than in $\mathrm{AD}$ and controls, but these differences were not statistically significant [105]. Interestingly, all the patients with $16311 \mathrm{C}$ variant were $H L A-D R 3$ positive [105], suggesting that there might be some interaction between this variant and $H L A-D R 3$, which is in a genomic region strongly associated with sIBM. Further studies are required to investigate whether this variant plays a pathogenic role in SIBM and/or its possible interaction with other genetic factors.

Recently a gene called 'Translocase of Outer Mitochondrial Membrane 40' (TOMM40) which is adjacent to and in linkage disequilibrium with the $A P O E$ locus on chromosome 19, has been implicated in AD [106]. TOMM40 encodes an outer mitochondrial membrane translocase facilitating the transport of unfolded proteins such as amyloid- $\beta$ from the cytosol into the mitochondrial intermembrane space [107]. A polyT repeat, an intronic polymorphism (rs10524523), in the TOMM40 gene together with the $A P O E$ genotypes has been shown to influence disease susceptibility of AD [108]. It has been reported that carriers of the $A P O E \varepsilon 3$ allele with a very long (VL) polyT repeat alleles in TOMM40 had reduced risk of sIBM compared to controls, and this was also associated with a later age at onset of symptoms [56]. The rs10524523 may modulate expression levels of TOMM40 and/or APOE to influence disease susceptibility. This also comes to a hypothesis that genetic variants of TOMM4O could be associated with altered mitochondrial pore function and transport of proteins into mitochondria. This could result in energy metabolism changes and increased reactive oxygen species formation, further contributing to the impairment in mitochondria and degeneration in muscle fibres [56]. 


\section{Future work - whole-exome sequencing and RNA sequencing}

Over the past five years, next-generation sequencing technologies have already shown considerable promises in the identification of rare variants associated not only with Mendelian but also with complex diseases. For example, rare variants in TREM2 were recently found to be associated with increased risk of Alzheimer's disease by using whole-genome and whole-exome sequencing (WES) [109]. Up to recently, most genome-wide studies were based on common SNPs thought to have small effects on disease, and thus large size cohorts were needed to find positive associations. The advent of WES enables now the identification of rare coding variants which are likely functional and likely show stronger effects, increasing the likelihood of detecting disease associated variants. This advantage of WES is particularly important for rare diseases like sIBM where the number of cases is probably not large enough for a conventional genome-wide association study (GWAS). Moreover, WES also enables the analysis of the whole set of genes belonging to candidate biochemical pathways in a very quick and cost effective way. These techniques have the potential to yield very interesting results, especially to uncover previously overlooked biological processes of complex disorders, linking results from studies on molecular data, clinical phenotypes and biological disease pathways. The description of mutations in the same genes causing different diseases highlights the important role of next-generation sequencing in uncovering pleiotropic events, particularly in neurodegenerative disorders [110]. Therefore, based on the International IBM Consortium Genetic Study (IIBMCGS), WES will be performed for 200 sIBM cases and 200 normal muscle controls by our group. So far, only 19 sIBM cases have been exome sequenced in an American group [44], but no further data has been reported. Our study, currently with 160 recruited sIBM cases, is the largest sIBM cohort to date. We expected to identify a number of rare sIBM variants that cluster in disease associated genes. Replication of these findings will be verified in a further 700 sIBM cases and 2200 controls. It is also worthwhile to combine with other techniques, such as genotyping, haplotyping for $H L A$ gene, fragment analysis for repeat variants, and comparative genomic hybridization $(\mathrm{CGH})$ analysis for copy number variants which cannot be detected by WES.

In the future, besides genetic defects identified in SIBM, RNA sequencing in muscle tissue and lymphoblast lines will identify transcriptomic profiles and expression quantitative trait loci (eQTL) in sIBM and other inflammatory myopathies. The application of RNA sequencing will also allow us to study and dissect splicing abnormalities which may not be detected by exon arrays. Investigating the transcriptomic and genomic factors will be important in revealing dysregulated molecular pathways in these disorders, identifying a diagnostic signature in blood and revealing biomarkers for future therapeutic strategies. A searchable database to the research community is also planned to build up to integrate WES, RNA sequencing and eQTL data, further to aligned with the biobank database with disease progression, response to treatment and muscle imaging.

\section{Conclusion}

In conclusion, sIBM remains an enigmatic muscle disorder even though it has been about half a century since the first case was described. The primary pathogenesis of sIBM is still controversial, but it is more likely to due to multifactorial mechanisms, including immune changes, degenerative changes, mitochondrial abnormalities and the ageing milieu in the muscle fibres, which involve a complex interaction between environmental triggers (possibly viral) and genetic susceptibility. Despite the strikingly phenotypic similarities between sIBM muscle fibres and the brains of $\mathrm{AD}$, research on the candidate genes encoding the deposited proteins have not shown any positive result so far. Genes located within the MHC region are still the most strongly associated candidates with sIBM. Genes linked to hIBM and pathologically sIBM-like myopathies may provide important clues for sIBM genetic research. Effective WES and RNA sequencing analysis of a large sIBM cohort will significantly contribute to our knowledge in this under-explored area.

\section{Search strategy}

References for this Review were identified by searches in PubMed between 1969 and May 2014. The search terms "inclusion body myositis", "inclusion body myopathy", "IBM", "rimmed vacuolar myopathy", and "inflammatory myopathy" were used. References were also identified from the bibliography of the identified articles. Only papers published in English or with available English translations of relevant data were reviewed. The final reference list was generated on the basis of relevance to the topics covered in this Review.

\section{Competing interests \\ The authors declare that they have no competing interests.}

\section{Authors' contributions}

QG contributed to the literature search and to drafting the manuscript. All authors contributed to the critical revision process and approved the final manuscript. $\mathrm{MGH}, \mathrm{HH}$, and $\mathrm{PM}$ are principal investigators of the International IBM Consortium Genetic Study (IIBMCGS).

\section{Acknowledgements}

Q.G. is supported by a UCL Impact Studentship and the Chinese Scholarship Council. M.G.H. is supported by an MRC Centre grant 2013-2018 (MR/K000608/ 01). C.B. is also supported by the MRC. The International IBM Consortium Genetic Study (IIBMCGS) is also supported by an MRC grant (MR/J004758/1). We thank all the study collaborators from UK, USA, and Europe, and especially thank all the patients and their families for participating in our study. 
Received: 14 April 2014 Accepted: 12 June 2014

Published: 19 June 2014

\section{References}

1. Needham M, Corbett A, Day T, Christiansen F, Fabian V, Mastaglia FL: Prevalence of sporadic inclusion body myositis and factors contributing to delayed diagnosis. J Clin Neurosci 2008, 15:1350-1353.

2. Lindberg C, Persson LI, Bjorkander J, Oldfors A: Inclusion body myositis: clinical, morphological, physiological and laboratory findings in 18 cases. Acta Neurol Scand 1994, 89:123-131.

3. Badrising UA, Maat-Schieman M, van Duinen SG, Breedveld F, van Doorn $P$, van Engelen B, van den Hoogen F, Hoogendijk J, Howeler C, de Jager A, Jennekens $F$, Koehler $P$, van der Leeuw $H$, de Visser M, Verschuuren JJ, Wintzen AR: Epidemiology of inclusion body myositis in the Netherlands: a nationwide study. Neurology 2000, 55:1385-1387.

4. Kaipiainen-Seppanen O, Aho K: Incidence of rare systemic rheumatic and connective tissue diseases in Finland. J Intern Med 1996, 240:81-84.

5. Phillips BA, Zilko PJ, Mastaglia FL: Prevalence of sporadic inclusion body myositis in Western Australia. Muscle Nerve 2000, 23:970-972.

6. Felice KJ, North WA: Inclusion body myositis in Connecticut: observations in 35 patients during an 8-year period. Medicine (Baltimore) 2001, 80:320-327.

7. Wilson FC, Ytterberg SR, St Sauver JL, Reed AM, St Sauver JL, Reed AM: Epidemiology of sporadic inclusion body myositis and polymyositis in Olmsted County, Minnesota. J Rheumatol 2008, 35:445-447.

8. Oflazer PS, Deymeer F, Parman Y: Sporadic-inclusion body myositis (s-IBM) is not so prevalent in Istanbul/Turkey: a muscle biopsy based survey. Acta Myol 2011, 30:34-36.

9. Suzuki N, Aoki M, Mori-Yoshimura M, Hayashi YK, Nonaka I, Nishino I: Increase in number of sporadic inclusion body myositis (sIBM) in Japan. J Neurol 2012, 259:554-556.

10. Tan JA, Roberts-Thomson PJ, Blumbergs P, Hakendorf P, Cox SR, Limaye V: Incidence and prevalence of idiopathic inflammatory myopathies in South Australia: a 30-year epidemiologic study of histology-proven cases. Int J Rheum Dis 2013, 16:331-338.

11. Machado P, Brady S, Hanna MG: Update in inclusion body myositis. Curr Opin Rheumatol 2013, 25:763-771.

12. Cortese A, Machado P, Morrow J, Dewar L, Hiscock A, Miller A, Brady S, Hilton-Jones D, Parton M, Hanna MG: Longitudinal observational study of sporadic inclusion body myositis: implications for clinical trials. Neuromuscul Disord 2013, 23:404-412.

13. Cox FM, Titulaer MJ, Sont JK, Wintzen AR, Verschuuren JJ, Badrising UA: A 12-year follow-up in sporadic inclusion body myositis: an end stage with major disabilities. Brain 2011, 134:3167-3175.

14. Muntzing K, Lindberg C, Moslemi AR, Oldfors A: Inclusion body myositis: clonal expansions of muscle-infiltrating T cells persist over time. Scand I Immunol 2003, 58:195-200.

15. Askanas V, Engel WK: Inclusion-body myositis: newest concepts of pathogenesis and relation to aging and Alzheimer disease. J Neuropathol Exp Neurol 2001, 60:1-14.

16. Oldfors A, Moslemi AR, Jonasson L, Ohlsson M, Kollberg G, Lindberg C: Mitochondrial abnormalities in inclusion-body myositis. Neurology 2006, 66:S49-S55.

17. Griggs RC, Askanas V, DiMauro S, Engel A, Karpati G, Mendell JR, Rowland LP: Inclusion body myositis and myopathies. Ann Neurol 1995, 38:705-713.

18. Tawil R, Griggs RC: Inclusion body myositis. Curr Opin Rheumatol 2002, 14:653-657.

19. Verschuuren JJ, Badrising UA, Van Engelen BG, Van der Hoeven $\mathrm{JH}$, Hoogendijk J, Wintzen AR: Inclusion body myositis. In Diagnostic Criteria for Neuromuscular Disorders. Edited by Emery AEH. London: Royal Society of Medicine Press; 1997:81-84

20. Rose MR: 188th ENMC International Workshop: Inclusion Body Myositis, 2-4 December 2011, Naarden, The Netherlands. Neuromuscul Disord 2013, 23:1044-1055

21. Hilton-Jones D, Miller A, Parton M, Holton J, Sewry C, Hanna MG: Inclusion body myositis: MRC Centre for Neuromuscular Diseases, IBM workshop, London, 13 June 2008. Neuromuscul Disord 2010, 20:142-147.

22. Benveniste $\mathrm{O}$, Hilton-Jones D: International Workshop on Inclusion Body Myositis held at the Institute of Myology, Paris, on 29 May 2009. Neuromuscul Disord 2010, 20:414-421.
23. Greenberg SA: Pathogenesis and therapy of inclusion body myositis. Curr Opin Neurol 2012, 25:630-639.

24. Ranque-Francois B, Maisonobe T, Dion E, Piette JC, Chauveheid MP, Amoura Z, Papo T: Familial inflammatory inclusion body myositis. Ann Rheum Dis 2005, 64:634-637.

25. Sivakumar K, Semino-Mora C, Dalakas MC: An inflammatory, familial, inclusion body myositis with autoimmune features and a phenotype identical to sporadic inclusion body myositis. Studies in three families. Brain 1997, 120(Pt 4):653-661.

26. Tateyama M, Saito N, Fujihara K, Shiga Y, Takeda A, Narikawa K, Hasegawa T, Taguchi Y, Sakuma R, Onodera Y, Ohnuma A, Tobita M, Itoyama Y: Familial inclusion body myositis: a report on two Japanese sisters. Intern Med 2003, 42:1035-1038.

27. Amato AA, Shebert RT: Inclusion body myositis in twins. Neurology 1998, 51:598-600

28. Askanas V, Engel WK: Inclusion-body myositis and myopathies: different etiologies, possibly similar pathogenic mechanisms. Curr Opin Neurol 2002, 15:525-531.

29. Needham M, Mastaglia FL, Garlepp MJ: Genetics of inclusion-body myositis. Muscle Nerve 2007, 35:549-561.

30. Di Blasi C, Mora M, Pareyson D, Farina L, Sghirlanzoni A, Vignier N, Blasevich F, Cornelio F, Guicheney P, Morandi L: Partial laminin alpha2 chain deficiency in a patient with myopathy resembling inclusion body myositis. Ann Neurol 2000, 47:811-816.

31. Ferrer I, Martin B, Castano JG, Lucas JJ, Moreno D, Olive M: Proteasomal expression, induction of immunoproteasome subunits, and local MHC class I presentation in myofibrillar myopathy and inclusion body myositis. J Neuropathol Exp Neurol 2004, 63:484-498.

32. Cai H, Yabe I, Sato K, Kano T, Nakamura M, Hozen H, Sasaki H: Clinical, pathological, and genetic mutation analysis of sporadic inclusion body myositis in Japanese people. J Neurol 2012, 259:1913-1922.

33. Dalakas MC: Interplay between inflammation and degeneration: using inclusion body myositis to study "neuroinflammation". Ann Neurol 2008, 64:1-3.

34. Dalakas MC: Inflammatory, immune, and viral aspects of inclusion-body myositis. Neurology 2006, 66:S33-S38.

35. Rygiel KA, Miller J, Grady JP, Rocha MC, Taylor RW, Turnbull DM: Mitochondrial and inflammatory changes in sporadic Inclusion Body Myositis. Neuropathol Appl Neurobiol 2014. doi:10.1111/nan.12149.

36. Askanas V, Engel WK: Molecular pathology and pathogenesis of inclusion-body myositis. Microsc Res Tech 2005, 67:114-120.

37. Askanas $V$, Engel WK, Nogalska A: Inclusion body myositis: a degenerative muscle disease associated with intra-muscle fiber multi-protein aggregates, proteasome inhibition, endoplasmic reticulum stress and decreased lysosomal degradation. Brain Pathol 2009, 19:493-506.

38. Jaworska-Wilczynska M, Wilczynski GM, Engel WK, Strickland DK, Weisgraber $\mathrm{KH}$, Askanas V: Three lipoprotein receptors and cholesterol in inclusion-body myositis muscle. Neurology 2002, 58:438-445.

39. Yang CC, Alvarez RB, Engel WK, Askanas V: Increase of nitric oxide synthases and nitrotyrosine in inclusion-body myositis. Neuroreport 1996, 8:153-158.

40. Fratta P, Engel WK, Van Leeuwen FW, Hol EM, Vattemi G, Askanas V: Mutant ubiquitin UBB +1 is accumulated in sporadic inclusion-body myositis muscle fibers. Neurology 2004, 63:1114-1117.

41. Nogalska A, D’Agostino C, Terracciano C, Engel WK, Askanas V: Impaired autophagy in sporadic inclusion-body myositis and in endoplasmic reticulum stress-provoked cultured human muscle fibers. Am J Pathol 2010, 177:1377-1387.

42. Karpati G, O'Ferrall EK: Sporadic inclusion body myositis: pathogenic considerations. Ann Neurol 2009, 65:7-11.

43. Kok CC, Croager EJ, Witt CS, Kiers L, Mastaglia FL, Abraham LJ, Garlepp MJ: Mapping of a candidate region for susceptibility to inclusion body myositis in the human major histocompatibility complex. Immunogenetics 1999, 49:508-516.

44. Larman HB, Salajegheh M, Nazareno R, Lam T, Sauld J, Steen H, Kong SW, Pinkus JL, Amato AA, Elledge SJ, Greenberg SA: Cytosolic 5'-nucleotidase 1A autoimmunity in sporadic inclusion body myositis. Ann Neurol 2013, 73:408-418.

45. Askanas V, Alvarez RB, Engel WK: beta-Amyloid precursor epitopes in muscle fibers of inclusion body myositis. Ann Neurol 1993, 34:551-560. 
46. Askanas V, Engel WK, Yang CC, Alvarez RB, Lee VM, Wisniewski T: Light and electron microscopic immunolocalization of presenilin 1 in abnormal muscle fibers of patients with sporadic inclusion-body myositis and autosomal-recessive inclusion-body myopathy. Am J Pathol 1998, 152:889-895.

47. Cacciottolo M, Nogalska A, D'Agostino C, Engel WK, Askanas V: Dysferlin is a newly identified binding partner of AbetaPP and it co-aggregates with amyloid-beta42 within sporadic inclusion-body myositis (s-IBM) muscle fibers. Acta Neuropathol 2013, 126:781-783.

48. Needham M, Hooper A, James I, van Bockxmeer F, Corbett A, Day T, Garlepp MJ, Mastaglia FL: Apolipoprotein epsilon alleles in sporadic inclusion body myositis: a reappraisal. Neuromuscul Disord 2008, 18:150-152.

49. Baker M, Litvan I, Houlden H, Adamson J, Dickson D, Perez-Tur J, Hardy J, Lynch T, Bigio E, Hutton M: Association of an extended haplotype in the tau gene with progressive supranuclear palsy. Hum Mol Genet 1999, 8:711-715.

50. Lampe J, Kitzler H, Walter MC, Lochmuller H, Reichmann H: Methionine homozygosity at prion gene codon 129 may predispose to sporadic inclusion-body myositis. Lancet 1999, 353:465-466.

51. Gossrau G, Gestrich B, Koch R, Wunderlich C, Schroder JM, Schroeder S, Reichmann H, Lampe JB: Apolipoprotein E and alpha-1-antichymotrypsin polymorphisms in sporadic inclusion body myositis. Eur Neurol 2004, 51:215-220

52. Weihl CC, Temiz P, Miller SE, Watts G, Smith C, Forman M, Hanson PI, Kimonis $V$, Pestronk A: TDP-43 accumulation in inclusion body myopathy muscle suggests a common pathogenic mechanism with frontotemporal dementia. J Neurol Neurosurg Psychiatry 2008, 79:1186-1189.

53. Pinkus $J$, Amato AA, Taylor JP, Greenberg SA: Abnormal distribution of heterogeneous nuclear ribonucleoproteins in sporadic inclusion body myositis. Neuromuscul Disord 2014, 24:611-616.

54. DeJesus-Hernandez M, Mackenzie IR, Boeve BF, Boxer AL, Baker M, Rutherford NJ, Nicholson AM, Finch NA, Flynn H, Adamson J, Kouri N, Wojtas A, Sengdy P, Hsiung GY, Karydas A, Seeley WW, Josephs KA, Coppola G, Geschwind DH, Wszolek ZK, Feldman H, Knopman DS, Petersen RC, Miller BL, Dickson DW, Boylan KB, Graff-Radford NR, Rademakers R: Expanded GGGGCC hexanucleotide repeat in noncoding region of C9ORF72 causes chromosome 9p-linked FTD and ALS. Neuron 2011, 72:245-256.

55. Moslemi AR, Lindberg C, Oldfors A: Analysis of multiple mitochondrial DNA deletions in inclusion body myositis. Hum Mutat 1997, 10:381-386.

56. Mastaglia FL, Rojana-Udomsart A, James I, Needham M, Day TJ, Kiers L, Corbett JA, Saunders AM, Lutz MW, Roses AD: Polymorphism in the TOMM40 gene modifies the risk of developing sporadic inclusion body myositis and the age of onset of symptoms. Neuromuscul Disord 2013, 23:969-974.

57. Garlepp MJ, Laing B, Zilko PJ, Ollier W, Mastaglia FL: HLA associations with inclusion body myositis. Clin Exp Immunol 1994, 98:40-45.

58. Badrising UA, Schreuder GM, Giphart MJ, Geleijns K, Verschuuren JJ, Wintzen AR, Maat-Schieman ML, van Doorn P, van Engelen BG, Faber CG, Hoogendijk JE, de Jager AE, Koehler PJ, de Visser M, van Duinen SG, Dutch IBM Study Group: Associations with autoimmune disorders and HLA class I and II antigens in inclusion body myositis. Neurology 2004, 63:2396-2398.

59. Koffman BM, Sivakumar K, Simonis T, Stroncek D, Dalakas MC: HLA allele distribution distinguishes sporadic inclusion body myositis from hereditary inclusion body myopathies. J Neuroimmunol 1998, 84:139-142.

60. Lampe JB, Gossrau G, Kempe A, Fussel M, Schwurack K, Schroder R, Krause S, Kohnen R, Walter MC, Reichmann H, Lochmuller H: Analysis of HLA class I and II alleles in sporadic inclusion-body myositis. J Neurol 2003, 250:1313-1317.

61. Mastaglia FL, Needham M, Scott A, James I, Zilko P, Day T, Kiers L, Corbett A, Witt CS, Allcock R, Laing N, Garlepp M, Christiansen FT: Sporadic inclusion body myositis: HLA-DRB1 allele interactions influence disease risk and clinical phenotype. Neuromuscul Disord 2009, 19:763-765.

62. Needham M, James I, Corbett A, Day T, Christiansen F, Phillips B, Mastaglia FL: Sporadic inclusion body myositis: phenotypic variability and influence of HLA-DR3 in a cohort of 57 Australian cases. J Neurol Neurosurg Psychiatry 2008, 79:1056-1060

63. Price P, Santoso L, Mastaglia F, Garlepp M, Kok CC, Allcock R, Laing N: Two major histocompatibility complex haplotypes influence susceptibility to sporadic inclusion body myositis: critical evaluation of an association with HLA-DR3. Tissue Antigens 2004, 64:575-580.
64. O'Hanlon TP, Carrick DM, Arnett FC, Reveille JD, Carrington M, Gao X, Oddis CV, Morel PA, Malley JD, Malley K, Dreyfuss J, Shamim EA, Rider LG, Chanock SJ, Foster CB, Bunch T, Plotz PH, Love LA, Miller FW: Immunogenetic risk and protective factors for the idiopathic inflammatory myopathies: distinct HLA-A, -B, -CW, -DRB1 and -DQA1 allelic profiles and motifs define clinicopathologic groups in caucasians. Medicine (Baltimore) 2005 , 84:338-349.

65. Rojana-udomsart A, James I, Castley A, Needham M, Scott A, Day T, Kiers L, Corbett A, Sue C, Witt C, Martinez P, Christiansen F, Mastaglia F: High-resolution HLA-DRB1 genotyping in an Australian inclusion body myositis (s-IBM) cohort: an analysis of disease-associated alleles and diplotypes. J Neuroimmunol 2012, 250:77-82.

66. Scott AP, Allcock RJ, Mastaglia F, Nishino I, Nonaka I, Laing N: Sporadic inclusion body myositis in Japanese is associated with the MHC ancestral haplotype 52.1. Neuromuscul Disord 2006, 16:311-315.

67. Rojana-udomsart A, Mitrpant C, James I, Witt C, Needham M, Day T, Kiers L, Corbett A, Martinez P, Wilton SD, Mastaglia FL: Analysis of HLA-DRB3 alleles and supertypical genotypes in the MHC Class II region in sporadic inclusion body myositis. J Neuroimmunol 2013, 254:174-177.

68. Scott AP, Laing NG, Mastaglia F, Needham M, Walter MC, Dalakas MC, Allcock RJ: Recombination mapping of the susceptibility region for sporadic inclusion body myositis within the major histocompatibility complex. J Neuroimmunol 2011, 235:77-83.

69. Scott AP, Laing NG, Mastaglia F, Dalakas M, Needham M, Allcock RJ: Investigation of NOTCH4 coding region polymorphisms in sporadic inclusion body myositis. J Neuroimmunol 2012, 250:66-70.

70. Salajegheh M, Lam T, Greenberg SA: Autoantibodies against a $43 \mathrm{KDa}$ muscle protein in inclusion body myositis. PLoS One 2011, 6:e20266.

71. Pluk H, van Hoeve BJ, van Dooren SH, Stammen-Vogelzangs J, van der Heijden A, Schelhaas HJ, Verbeek MM, Badrising UA, Arnardottir S, Gheorghe K, Lundberg IE, Boelens WC, van Engelen BG, Pruijn GJ: Autoantibodies to cytosolic 5'-nucleotidase $1 \mathrm{~A}$ in inclusion body myositis. Ann Neurol 2013, 73:397-407.

72. Ipata PL, Balestri F: The functional logic of cytosolic 5'-nucleotidases. Curr Med Chem 2013, 20:4205-4216.

73. Askanas V, Engel WK, Alvarez RB, Glenner GG: Beta-Amyloid protein immunoreactivity in muscle of patients with inclusion-body myositis. Lancet 1992, 339:560-561.

74. Sarkozi E, Askanas V, Johnson SA, Engel WK, Alvarez RB: Beta-Amyloid precursor protein mRNA is increased in inclusion-body myositis muscle. Neuroreport 1993, 4:815-818.

75. Masuda Y, Uemura S, Ohashi R, Nakanishi A, Takegoshi K, Shimizu T, Shirasawa T, Irie K: Identification of physiological and toxic conformations in Abeta42 aggregates. Chembiochem 2009, 10:287-295.

76. Nogalska A, D'Agostino C, Engel WK, Klein WL, Askanas V: Novel demonstration of amyloid-beta oligomers in sporadic inclusion-body myositis muscle fibers. Acta Neuropathol 2010, 120:661-666.

77. Abdo WF, van Mierlo T, Hengstman GJ, Schelhaas HJ, van Engelen BG, Verbeek MM: Increased plasma amyloid-beta42 protein in sporadic inclusion body myositis. Acta Neuropathol 2009, 118:429-431.

78. Sivakumar K, Cervenakova L, Dalakas MC, Leon-Monzon M, Isaacson SH, Nagle JW, Vasconcelos O, Goldfarb LG: Exons 16 and 17 of the amyloid precursor protein gene in familial inclusion body myopathy. Ann Neurol 1995, 38:267-269.

79. Weggen S, Beher D: Molecular consequences of amyloid precursor protein and presenilin mutations causing autosomal-dominant Alzheimer's disease. Alzheimers Res Ther 2012, 4:9.

80. Vetrivel KS, Thinakaran G: Amyloidogenic processing of beta-amyloid precursor protein in intracellular compartments. Neurology 2006, 66:S69-S73.

81. Barthelemy F, Wein N, Krahn M, Levy N, Bartoli M: Translational research and therapeutic perspectives in dysferlinopathies. Mol Med 2011, 17:875-882.

82. Mirabella M, Alvarez RB, Engel WK, Weisgraber KH, Askanas V: Apolipoprotein $\mathrm{E}$ and apolipoprotein $\mathrm{E}$ messenger RNA in muscle of inclusion body myositis and myopathies. Ann Neurol 1996, 40:864-872.

83. Askanas V, Mirabella M, Engel WK, Alvarez RB, Weisgraber $\mathrm{KH}$ : Apolipoprotein $\mathrm{E}$ immunoreactive deposits in inclusion-body muscle diseases. Lancet 1994, 343:364-365.

84. Garlepp MJ, Tabarias H, van Bockxmeer FM, Zilko PJ, Laing B, Mastaglia FL: Apolipoprotein E epsilon 4 in inclusion body myositis. Ann Neurol 1995, 38:957-959 
85. Askanas V, Engel WK, Mirabella M, Weisgraber KH, Saunders AM, Roses AD, McFerrin J: Apolipoprotein E alleles in sporadic inclusion-body myositis and hereditary inclusion-body myopathy. Ann Neurol 1996, 40:264-265.

86. Harrington CR, Anderson JR, Chan KK: Apolipoprotein E type epsilon 4 allele frequency is not increased in patients with sporadic inclusion-body myositis. Neurosci Lett 1995, 183:35-38.

87. Love S, Nicoll JA, Lowe J, Sherriff F: Apolipoprotein E allele frequencies in sporadic inclusion body myositis. Muscle Nerve 1996, 19:1605-1607.

88. Maurage CA, Bussiere T, Sergeant N, Ghesteem A, Figarella-Branger D, Ruchoux MM, Pellissier JF, Delacourte A: Tau aggregates are abnormally phosphorylated in inclusion body myositis and have an immunoelectrophoretic profile distinct from other tauopathies. Neuropathol Appl Neurobiol 2004, 30:624-634.

89. van Slegtenhorst M, Lewis J, Hutton M: The molecular genetics of the tauopathies. Exp Gerontol 2000, 35:461-471.

90. Bilak M, Askanas V, Engel WK: Strong immunoreactivity of alpha 1-antichymotrypsin co-localizes with beta-amyloid protein and ubiquitin in vacuolated muscle fibers of inclusion-body myositis. Acta Neuropathol 1993, 85:378-382.

91. Kamboh MI, Sanghera DK, Ferrell RE, DeKosky ST: APOE*4-associated Alzheimer's disease risk is modified by alpha 1-antichymotrypsin polymorphism. Nat Genet 1995, 10:486-488.

92. Sarkozi E, Askanas V, Engel WK: Abnormal accumulation of prion protein mRNA in muscle fibers of patients with sporadic inclusion-body myositis and hereditary inclusion-body myopathy. Am J Pathol 1994, 145:1280-1284

93. Askanas V, Bilak M, Engel WK, Alvarez RB, Tome F, Leclerc A: Prion protein is abnormally accumulated in inclusion-body myositis. Neuroreport 1993, 5:25-28.

94. Lampe J, Gossrau G, Reichmann H, Walter MC, Mendel B, Lochmuller H: Prion codon 129 homozygosity and sporadic inclusion body myositis. Neurology 2001, 57:368.

95. Kabashi E, Valdmanis PN, Dion P, Spiegelman D, McConkey BJ, Vande Velde C, Bouchard JP, Lacomblez L, Pochigaeva K, Salachas F, Pradat PF, Camu W, Meininger $V$, Dupre $N$, Rouleau GA: TARDBP mutations in individuals with sporadic and familial amyotrophic lateral sclerosis. Nat Genet 2008, 40:572-574.

96. Hernandez Lain A, Millecamps S, Dubourg O, Salachas F, Bruneteau G, Lacomblez L, LeGuern E, Seilhean D, Duyckaerts C, Meininger V, Mallet J, Pradat PF: Abnormal TDP-43 and FUS proteins in muscles of sporadic IBM: similarities in a TARDBP-linked ALS patient. J Neurol Neurosurg Psychiatry 2011, 82:1414-1416.

97. Olive M, Janue A, Moreno D, Gamez J, Torrejon-Escribano B, Ferrer I: TAR DNA-Binding protein 43 accumulation in protein aggregate myopathies. J Neuropathol Exp Neurol 2009, 68:262-273.

98. Salajegheh M, Pinkus JL, Taylor JP, Amato AA, Nazareno R, Baloh RH, Greenberg SA: Sarcoplasmic redistribution of nuclear TDP-43 in inclusion body myositis. Muscle Nerve 2009, 40:19-31.

99. Ramaswami M, Taylor JP, Parker R: Altered ribostasis: RNA-protein granules in degenerative disorders. Cell 2013, 154:727-736.

100. Kim HJ, Kim NC, Wang YD, Scarborough EA, Moore J, Diaz Z, MacLea KS, Freibaum B, Li S, Molliex A, Kanagaraj AP, Carter R, Boylan KB, Wojtas AM, Rademakers R, Pinkus JL, Greenberg SA, Trojanowski JQ, Traynor BJ, Smith BN, Topp S, Gkazi AS, Miller J, Shaw CE, Kottlors M, Kirschner J, Pestronk A, Li YR, Ford AF, Gitler AD, et al: Mutations in prion-like domains in hnRNPA2B1 and hnRNPA1 cause multisystem proteinopathy and ALS. Nature 2013, 495:467-473.

101. Bieniek KF, Murray ME, Rutherford NJ, Castanedes-Casey M, DeJesus-Hernandez M, Liesinger AM, Baker MC, Boylan KB, Rademakers R, Dickson DW: Tau pathology in frontotemporal lobar degeneration with C9ORF72 hexanucleotide repeat expansion. Acta Neuropathol 2013, 125:289-302.

102. Rifai Z, Welle S, Kamp C, Thornton CA: Ragged red fibers in normal aging and inflammatory myopathy. Ann Neurol 1995, 37:24-29.

103. Oldfors A, Larsson NG, Lindberg C, Holme E: Mitochondrial DNA deletions in inclusion body myositis. Brain 1993, 116(Pt 2):325-336.

104. Santorelli FM, Sciacco M, Tanji K, Shanske S, Vu TH, Golzi V, Griggs RC, Mendell JR, Hays AP, Bertorini TE, Pestronk A, Bonilla E, DiMauro S: Multiple mitochondrial DNA deletions in sporadic inclusion body myositis: a study of 56 patients. Ann Neurol 1996, 39:789-795.

105. Kok CC, Boyt A, Gaudieri S, Martins R, Askanas V, Dalakas M, Kiers L, Mastaglia F, Garlepp M: Mitochondrial DNA variants in inclusion body myositis. Neuromuscul Disord 2000, 10:604-611.
106. Guerreiro RJ, Hardy J: TOMM40 association with Alzheimer disease: tales of APOE and linkage disequilibrium. Arch Neurol 2012, 69:1243-1244.

107. Hansson Petersen CA, Alikhani N, Behbahani H, Wiehager B, Pavlov PF, Alafuzoff I, Leinonen V, Ito A, Winblad B, Glaser E, Ankarcrona M: The amyloid beta-peptide is imported into mitochondria via the TOM import machinery and localized to mitochondrial cristae. Proc Natl Acad Sci U S A 2008, 105:13145-13150.

108. Roses AD, Lutz MW, Crenshaw DG, Grossman I, Saunders AM, Gottschalk WK: TOMM40 and APOE: Requirements for replication studies of association with age of disease onset and enrichment of a clinical trial. Alzheimers Dement 2013, 9:132-136.

109. Guerreiro R, Wojtas A, Bras J, Carrasquillo M, Rogaeva E, Majounie E, Cruchaga C, Sassi C, Kauwe JS, Younkin S, Hazrati L, Collinge J, Pocock J, Lashley T, Williams J, Lambert JC, Amouyel P, Goate A, Rademakers R, Morgan K, Powell J, St George-Hyslop P, Singleton A, Hardy J, Alzheimer Genetic Analysis Group: TREM2 variants in Alzheimer's disease. N Engl J Med 2013, 368:117-127.

110. Guerreiro R, Bras J, Hardy J, Singleton A: Next generation sequencing techniques in neurological diseases: redefining clinical and molecular associations. Hum Mol Genet 2014. doi:10.1093/hmg/ddu203.

\section{doi:10.1186/1750-1172-9-88}

Cite this article as: Gang et al:: Sporadic inclusion body myositis: the genetic contributions to the pathogenesis. Orphanet Journal of Rare Diseases 2014 9:88.

\section{Submit your next manuscript to BioMed Central and take full advantage of:}

- Convenient online submission

- Thorough peer review

- No space constraints or color figure charges

- Immediate publication on acceptance

- Inclusion in PubMed, CAS, Scopus and Google Scholar

- Research which is freely available for redistribution

Submit your manuscript at www.biomedcentral.com/submit
C Biomed Central 